\title{
COVID-19 case fatality rate in the context of healthcare system organization and EHCI performance: Focus on the Visegrad (V4) countries
}

\author{
PETER PAŽITNÝ ${ }^{1^{*}}$ (1), DANIELA KANDILAKI ${ }^{1}$ (0), ROMAN MUŽIK ${ }^{2}$ and \\ BEÁTA BENKOVÁ ${ }^{2}$
}

\author{
${ }^{1}$ Faculty of Management, Prague University of Economics and Business, Jarošovská 1117/II, 37701 \\ Jindřichův Hradec, Czech Republic \\ ${ }^{2}$ Dôvera Health Insurance Company, Inc, Bratislava, Slovakia
}

Received: June 1, 2021 • Revised manuscript received: July 2, 2021 • Accepted: August 15, 2021

(C) 2021 Akadémiai Kiadó, Budapest

\begin{abstract}
This article tries to explain the differences in COVID-19 case fatality rate (CFR) in 22 European countries by their type of organization and performance level of their healthcare systems. The CFR is taken here as the most important indicator since it measures the ratio between COVID deaths and COVID cases. In our view, this indicator reflects the true performance of the healthcare system, as this indicator is freed form public health interventions, like testing, lockdowns or social distancing.

Our research is also unique, because it sees the healthcare system in a holistic way and tries to explain the CFR not by individual risk factors, socioeconomic indicators, or partial system parameters, but by using a complex healthcare system classification method adopted from Isabelle Joumard and an overall healthcare system performance index adopted from European Health Consumer Index (EHCI).

The main results are twofold. First, higher EHCI score is related to lower CFR. So, the countries are cumulated basically in two quadrants: High EHCI performers (score 790 and higher) with low CFR (below 1.93\%) and low EHCI performers with high COVID CFR. Second, apart from Czech Republic, the V4 countries are not doing very well in fighting COVID. Hungary is the worst, not only from the V4 group, but the worst from the whole list of 22 European countries included in this research. Poland is doing better, but still is high above the median CFR. Slovakia was the second worst from the V4 group. Czech Republic is the best V4 performer and the only country with EHCI score lower than median and CFR also lower than the median.
\end{abstract}

*Corresponding author. E-mail: peter.pazitny@vse.cz 


\section{KEYWORDS}

COVID-19, case fatality rate, healthcare, organization, performance, EHCI, V4

\section{JEL CLASSIFICATION INDICES}

$|13| 14,, \mid 15$

\section{INTRODUCTION}

The first COVID-19 patient in Europe was diagnosed on January 24, 2020 (Lescure 2020). Until the date of writing this article in June 2021, more than 42 million cases were detected (Worldometers 2021a), which accounts to 7\% of Europe population. Out of these people, almost 1 million people died, setting the average European case fatality rate (CFR) at $2.3 \%$. In this context, some countries did significantly better, and some performed much worse (Table 1).

In this article we will try to explain the differences in COVID CFR by the type of organization of the healthcare system (Joumard 2010) and European Health Consumer Index performance - EHCI (Bjornberg 2019). Based on our literature search, on individual level, the COVID CFR can be affected by many factors, such as age/race composition of a given country, the prevalence of certain medical conditions that can lead more likely to severe complications, etc. This ratio also reflects the ability of the healthcare system to manage these conditions and especially chronic diseases. The aim of this paper is not search for further risk factors that explain the fatality rate on individual basis, but rather look at the CFR as a function of (1) the type of healthcare system organization and (2) the overall performance of the healthcare system.

The main indicator, in which we are interested is COVID CFR. This indicator shows, how many infected people die in the disease. In our view, this indicator reflects, how well (or badly) the healthcare system is able to treat the infected people. So, we are not focusing on the number of tested or infected, which rather falls under public health domain and does not necessarily describe the functioning of the healthcare system. In this context, CFR is a true performance indicator that reveals the ability of the healthcare system to deal with the disease.

In our paper, we will analyse a good number of European countries with focus on the Visegrad (V4) countries - Slovakia, Czech Republic, Poland and Hungary. ${ }^{1}$ Our main research questions are:

1. Can COVID case fatality rates be explained by the type of healthcare organization?

2. Is there a relationship between COVID case fatality rate and EHCI performance?

3. Is any of the EHCI sub-scores more relevant in explaining the performance gap of the V4 countries than the others?

\footnotetext{
${ }^{1}$ The Visegrad Group, Visegrad Four, or V4 is a cultural and political alliance of four countries of Central Europe (Czech Republic, Hungary, Poland and Slovakia), all of which are the members of the EU and of NATO, to advance cooperation in military, cultural, economic and energy matters with one another and to further their integration to the EU. The Group traces its origins to the summit meetings of leaders from Czechoslovakia, Hungary and Poland held in the Hungarian castle town of Visegrád on 15 February 1991. Visegrad was chosen as the location for the 1991 meeting as an intentional allusion to the medieval Congress of Visegrád in 1335 between John I of Bohemia, Charles I of Hungary and Casimir III of Poland. For a survey of economic development in the V4 countries, see Danska-Borsiak (2019).
} 
Table 1. Covid case fatality rate and related indicators in Europe

\begin{tabular}{|c|c|c|c|c|c|c|c|c|c|}
\hline & Joumard. 2010 & EHCI. score & $\begin{array}{l}\text { covid. } \\
\text { CASES }\end{array}$ & $\begin{array}{l}\text { covid. } \\
\text { DEATHS }\end{array}$ & $\begin{array}{l}\text { covid. } \\
\text { TESTS }\end{array}$ & population & area & $\begin{array}{l}\text { REAL.GDP. } \\
\text { per.capita }\end{array}$ & $\begin{array}{c}\text { CASE } \\
\text { FATALITY } \\
\text { RATE }\end{array}$ \\
\hline Country & $\begin{array}{c}\text { Classification of } \\
\text { healthcare } \\
\text { system (Groups } \\
1-6 \text { ) }\end{array}$ & $\begin{array}{l}\text { Performance } \\
\text { score (333- } \\
\text { 1000) }\end{array}$ & $\begin{array}{l}\text { Total covid } \\
\text { cases per } \\
\text { million }\end{array}$ & $\begin{array}{c}\text { Total covid } \\
\text { deaths per } \\
\text { million }\end{array}$ & $\begin{array}{l}\text { Total covid } \\
\text { tests per } \\
\text { million }\end{array}$ & $\begin{array}{c}\text { Total } \\
\text { population of } \\
\text { the country }\end{array}$ & $\begin{array}{l}\text { Total area } \\
\text { of the } \\
\text { country }\end{array}$ & $\begin{array}{l}\text { Real GDP } \\
\text { per capita }\end{array}$ & $\begin{array}{l}\text { covid. } \\
\text { DEATHS/ } \\
\text { covid. } \\
\text { CASES }\end{array}$ \\
\hline Switzerland & Group 1 & 893 & 74263 & 1213 & 772335 & 8575280 & 41291 & 60500 & 0.0163 \\
\hline Netherlands & Group 1 & 883 & 83648 & 990 & 686338 & 17344874 & 41540 & 40080 & 0.0118 \\
\hline Norway & Group 6 & 857 & 20087 & 135 & 918218 & 5347896 & 323772 & 68630 & 0.0067 \\
\hline Denmark & Group 5 & 855 & 42430 & 426 & 5917238 & 5814422 & 42924 & 48250 & 0.0100 \\
\hline Belgium & Group 2 & 849 & 82932 & 2056 & 1045229 & 11488980 & 30528 & 33560 & 0.0248 \\
\hline Finland & Group 5 & 839 & 15384 & 163 & 785623 & 5521606 & 338440 & 36140 & 0.0106 \\
\hline Luxembourg & Group 3 & 809 & 103779 & 1246 & 4098115 & 620001 & 2586 & 81290 & 0.0120 \\
\hline Sweden & Group 4 & 800 & 92447 & 1372 & 803124 & 10278887 & 438574 & 42370 & 0.0148 \\
\hline Austria & Group 3 & 799 & 66847 & 1111 & 3336305 & 8879920 & 83879 & 35490 & 0.0166 \\
\hline Iceland & Group 4 & 797 & 18628 & 85 & 1707754 & 360563 & 103000 & 36150 & 0.0046 \\
\hline France & Group 2 & 796 & 82713 & 1562 & 1123538 & 67248926 & 633186 & 30480 & 0.0189 \\
\hline Germany & Group 1 & 785 & 38548 & 973 & 643585 & 83092962 & 357376 & 34060 & 0.0252 \\
\hline Portugal & Group 5 & 754 & 81876 & 1667 & 987689 & 10286263 & 92226 & 17180 & 0.0204 \\
\hline Czechia & Group 3 & 731 & 150625 & 2691 & 1559273 & 10671870 & 78868 & 17250 & 0.0179 \\
\hline $\begin{array}{l}\text { United } \\
\quad \text { Kingdom }\end{array}$ & Group 6 & 728 & 64518 & 1868 & 2142220 & 66836327 & 248536 & 32910 & 0.0290 \\
\hline Slovakia & Group 1 & 722 & 69324 & 2088 & 463938 & 5454147 & 49035 & 15010 & 0.0301 \\
\hline
\end{tabular}


Table 1. Continued

\begin{tabular}{|c|c|c|c|c|c|c|c|c|c|}
\hline & Joumard. 2010 & EHCI. score & $\begin{array}{l}\text { covid. } \\
\text { CASES }\end{array}$ & $\begin{array}{l}\text { covid. } \\
\text { DEATHS }\end{array}$ & $\begin{array}{l}\text { covid. } \\
\text { TESTS }\end{array}$ & population & area & $\begin{array}{l}\text { REAL.GDP. } \\
\text { per.capita }\end{array}$ & $\begin{array}{c}\text { CASE } \\
\text { FATALITY } \\
\text { RATE }\end{array}$ \\
\hline Country & $\begin{array}{c}\text { Classification of } \\
\text { healthcare } \\
\text { system (Groups } \\
1-6)\end{array}$ & $\begin{array}{c}\text { Performance } \\
\text { score (333- } \\
1000)\end{array}$ & $\begin{array}{c}\text { Total covid } \\
\text { cases per } \\
\text { million }\end{array}$ & $\begin{array}{c}\text { Total covid } \\
\text { deaths per } \\
\text { million }\end{array}$ & $\begin{array}{l}\text { Total covid } \\
\text { tests per } \\
\text { million }\end{array}$ & $\begin{array}{l}\text { Total } \\
\text { population of } \\
\text { the country }\end{array}$ & $\begin{array}{c}\text { Total area } \\
\text { of the } \\
\text { country }\end{array}$ & $\begin{array}{l}\text { Real GDP } \\
\text { per capita }\end{array}$ & $\begin{array}{l}\text { covid. } \\
\text { DEATHS/ } \\
\text { covid. } \\
\text { CASES }\end{array}$ \\
\hline Italy & Group 6 & 687 & 64927 & 1960 & 931448 & 59729081 & 302073 & 24640 & 0.0302 \\
\hline Ireland & Group 6 & 669 & 49237 & 977 & 873317 & 4934340 & 69797 & 61560 & 0.0198 \\
\hline Greece & Group 3 & 615 & 31439 & 943 & 740954 & 10721582 & 132049 & 16300 & 0.0300 \\
\hline Poland & Group 6 & 585 & 72518 & 1711 & 367645 & 37965475 & 312679 & 12680 & 0.0236 \\
\hline Hungary & Group 6 & 565 & 79290 & 2719 & 542869 & 9771141 & 93011 & 12640 & 0.0343 \\
\hline
\end{tabular}

Source: Eurostat (2021), Worldometers (2021b), own calculation. 
To answer these research questions, we will use quantitative statistical methods.

\section{LITERATURE REVIEW}

In the literature, we can find several types of studies on COVID that can bring the light on CFR. The first types are studies on medical risk factors that can cause death of COVID. These factors are either certain conditions or certain diseases. People most at risk of getting seriously ill are known as clinically extremely vulnerable. These are patients who are having chemotherapy or antibody treatment for cancer, including immunotherapy, having an intense course of radiotherapy (radical radiotherapy) for lung cancer, having targeted cancer treatments that can affect the immune system (such as protein kinase inhibitors or PARP inhibitors), have blood or bone marrow cancer (such as leukaemia, lymphoma or myeloma) or bone marrow or stem cell transplantation in the past 6 months, have had an organ transplant and some other conditions (NHS 2021).

People with cancer ${ }^{2}$, diabetes ${ }^{3}$; chronic lung diseases, including $\mathrm{COPD}^{4}$, asthma ${ }^{5}$, interstitial lung disease, cystic fibrosis, pulmonary hypertension ${ }^{6}$, chronic kidney disease ${ }^{7}$, heart conditions $^{8}$, liver disease ${ }^{9}$, obesity ${ }^{10}$, stroke $^{11}$ and dementia ${ }^{12}$ are more vulnerable to developing a severe illness if they do get the COVID coronavirus. After a closer look, it is obvious that chronic diseases dominate the list.

The second type of studies focuses on socioeconomic, public health or environmental determinants. Multivariable regression model confirmed that inter-country variation in COVID death rates can be explained mainly by the obesity rate, the hypertension rate and population density. Life expectancy, the percentage of the population aged older than 65 years, the percentage of the population aged younger than 15 years, the delay in imposing national COVID control measures, per capita GDP, and mean temperature (with a negative coefficient indicating an association between higher national temperatures and lower death rates) are also associated with the death rate (Gardiner et al. 2021).

\footnotetext{
${ }^{2}$ Cancer Research UK (2021).

${ }^{3}$ Mainly older or/and having a high HbA1c or having a history of diabetes-related complications. By measuring glycated haemoglobin $(\mathrm{HbAlc})$, clinicians are able to get an overall picture of what our average blood sugar levels have been over a period of approximately 6-8 weeks (The British Diabetic Association 2021; American Diabetes Association 2021).

${ }^{4}$ Chronic obstructive pulmonary disease.

${ }^{5}$ Severe asthma or have a history of asthma attacks (Asthma UK and British Lung Foundation Partnership 2021).

${ }^{6} \mathrm{CDC}$ (2021a).

${ }^{7}$ National Kidney Foundation (2021).

${ }^{8}$ Heart failure, coronary artery disease, cardiomyopathies or hypertension (Clark et al. 2021; British Heart Foundation 2021).

${ }^{9}$ Liver transplant, patients on immunosuppressants (British Liver Trust 2021).

${ }^{10} \mathrm{BMI}$ of $\geq 40 \mathrm{~kg} \mathrm{~m}^{-2} \mathrm{CDC}$ (2021b).

${ }^{11}$ Stroke Association (2021).

${ }^{12}$ Wang et al. (2021).
} 
According to Adams (2021) for most of 167 countries for which obesity and death data were available about one-third of the difference in COVID death rates was due to obesity while in countries with obesity $<15 \%$, consistently low death rates were not associated with obesity. The risk for severe illness with COVID increases with age, with older adults at highest risk (CDC 2021c; Liang et al. 2020).

More than $80 \%$ of the COVID deaths occur in people over age 65 , and more than $95 \%$ of the COVID deaths occur in people older than 45 (CDC2021a). In line with the nonlinear nonparametric models, the risk factors referring to socioeconomic are most correlated with the COVID death rate, followed by risk factors referring to demographic, commuting to work, atmosphere, health status, land cover, disaster and climate (Luo et al. 2021).

The third type of studies look at partial indicators of health systems. According to Mattiuzzi et al. (2021), the COVID death rate in the EU countries (mean $1.9 \pm 0.8 \%$ ) was inversely associated with the number of available general hospitals, physicians and nurses. Significant positive associations were also found with the rate of acute care bed occupancy. Total healthcare expenditure, public sector health expenditure and the number of hospital and acute care beds did not influence the COVID death rate.

According to Liang et al. (2020), COVID mortality rate was negatively associated with COVID test number per 100 people $(\mathrm{RR}=0.92, P$-value $=0.001)$, government effectiveness score $(\mathrm{RR}=0.96, P$-value $=0.017)$, and number of hospital beds $(\mathrm{RR}=0.85, P<0.001)$. Furthermore, the negative association between COVID mortality and test number was stronger among the low-income countries and the countries with lower government effectiveness scores, younger populations and fewer hospital beds.

There are also many other determinants in literature describing the different relationships between COVID contagion and death rate as prevalence of Black and Hispanic populations (Cheng et al. 2020), partisanship (Gadarian et al. 2021), average Y-DNA haplogroup percentages (Delanghe et al. 2020; Ibrahim - Salih 2021; Schillaci 2021), cosmopolitanism, government efficiency and public trust in institutions (Dincă et al. 2020; Ruck et al. 2021), transport infrastructure quality score (Liang et al. 2020), commuting via public transportation and driving into work (relative to telecommuting), higher home values, higher summer temperatures and lower winter temperatures (Knittel - Ozaltun 2020), density of the population (Doti 2020), households with a mortgage, land cover with forest, people living in group quarter and airborne benzene concentration (Luo et al. 2021) and so on. These indicators should be considered in the overall assessment of the COVID pandemic, but from the perspective of this study, their impact on CFR should be negligible.

As we can see from the above, most of the studies focused on risk factors, which the proper disease management can reduce the mortality of COVID. Several studies look at the socioeconomic aspects as well as the impact of the environment. Relatively few research describes the performance of the health systems, and those are available focus on either public health or partial indicators of the system. There is an absolute lack of studies that focus on variability on CFR with the holistic view on the organization of health systems as an aggregate.

\section{METHODOLOGY AND DATA}

Isabelle Joumard (2010) classifies national healthcare systems according to: 
1. reliance on market mechanisms,

2. regulations to steer demand and supply,

3. coverage principles and budget and

4. management approaches to control public spending.

This methodology gives a new perspective on the healthcare system classification, a better one than the standard classification as "Bismarck/Beveridge"13 or "tax/social insurance" or "monopoly/competition".

The suitability of Joumard's methodology lies in deep institutional and organizational insight. Based on a standard classification, all V4 countries would be "Bismarck" with a main difference in monopoly/plurality in the number of health insurance funds. Monopoly is for Poland and Hungary and competition is for Slovakia and Czech Republic. But, according to this methodology, the V4 countries are classified into 3 groups.

Slovakia, together with Germany, Netherlands, and Switzerland share the group 1. Czech Republic is in group 3, which is very interesting, since Slovakia and Czech Republic, formed one unitary state for 74 years (1918-1992) and commonly re-adopted Bismarck in the early 90s after having the Semashko model post-WWII (Smatana 2016). The main reason that differentiates the two countries, are the neoliberal healthcare reforms in Slovakia during the years of 20022006 (Fisher et al. 2007). If we look at the two other V4 countries, Hungary and Poland share the same group 6.

To analyse the COVID CFR, only European countries (22) categorized into 6 groups will be used in a regression model (Fig. 1). Grouping according to Joumard will be used as dummy variables.

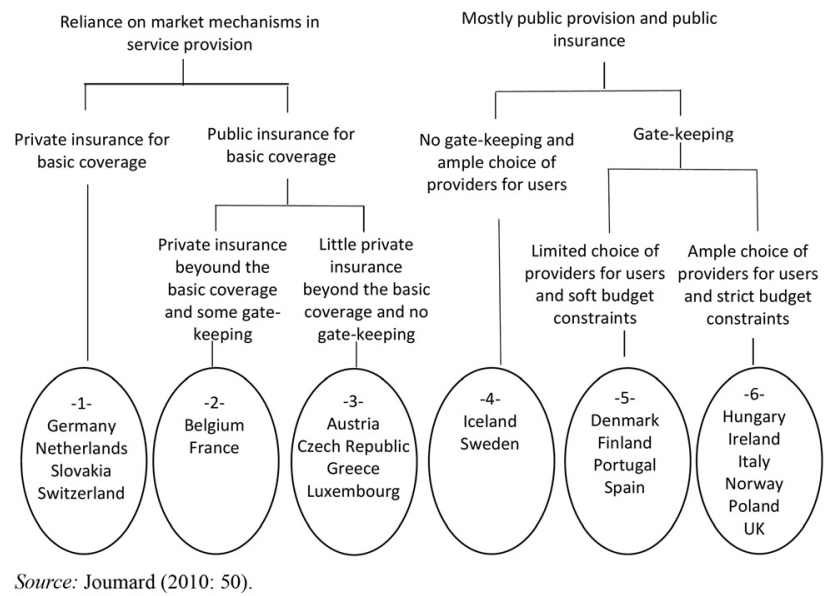

Fig. 1. Groups of countries sharing broadly similar institutions (European countries) Notes: The original classification also included Australia and Canada (group 2), Japan (Group 3), Turkey (Group 4), Mexico (Group 5) and New Zealand (Group 6).

\footnotetext{
${ }^{13}$ Kozuń-Cieślak, G. (2020).
} 


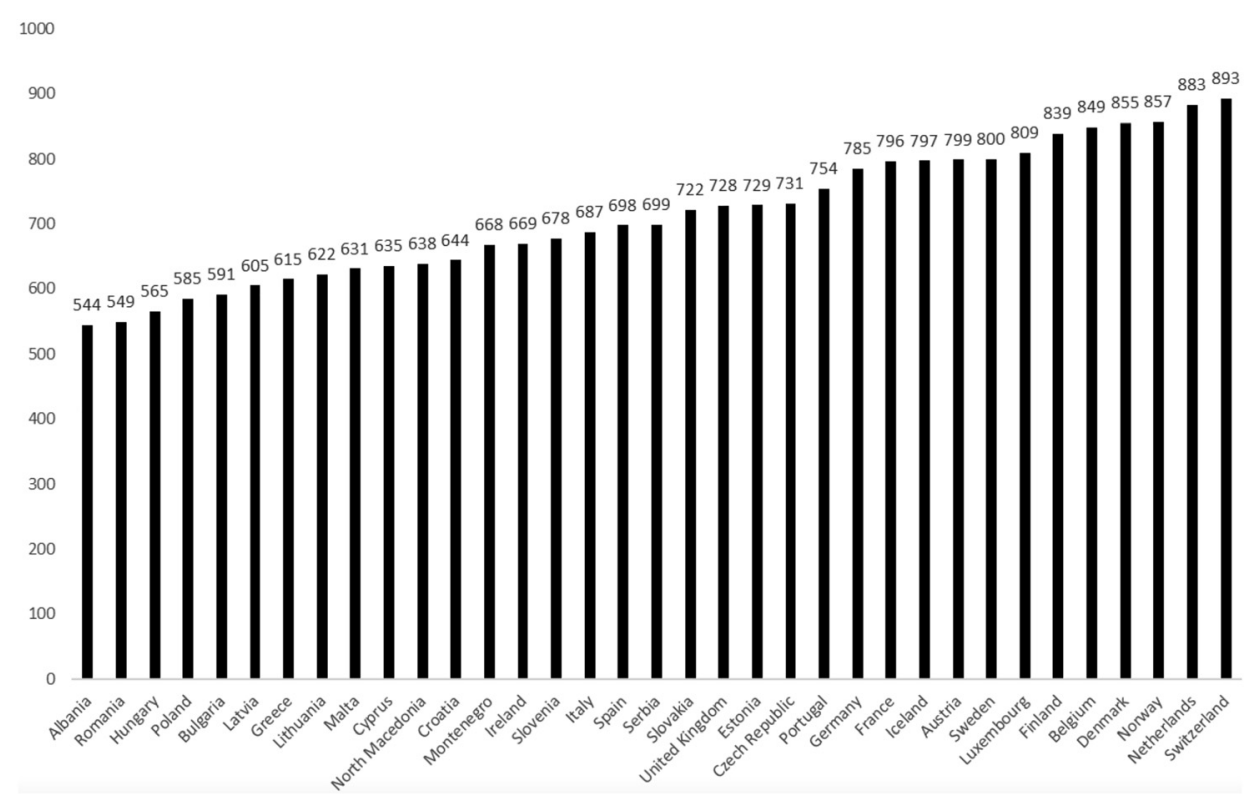

Source: Bjornberg (2019: 26).

Fig. 2. European Health Consumer Index (EHCl) 2018 total scores

EHCI, prepared annually by Health Consumer Powerhouse (Bjornberg 2019), is a widely accepted ranking of national healthcare systems according to their performance and consumer orientation. The first EHCI was published in 2005. The last index was published in 2018 and ranked Switzerland as the winner, closely followed by the Netherlands (Fig. 2). EHCI is unique while it provides complex performance measurement in 6 subcategories. The maximum number of points that a national healthcare system can get is 1000. So, EHCI provides not only an ordinal ranking (order), but also a cardinal ranking (score). This cardinal ranking will be used in our regression analysis.

As we mentioned earlier, the main objective of this paper is to look at the European countries, grouped by Joumard (2010) in 6 groups and ranked by EHCI into a cardinal ranking (points) to explain, if there are some important messages according to the management of COVID crisis in these countries. To assess the country performance in COVID, we use Worldometers data (2021), accessed on April 23, 2021. According to the European Centre for Disease Prevention and Control (ECDC 2021), in this time (week 16 in 2021), only $10 \%$ of the European population was fully vaccinated, so these CFRs from April 2021 should not be influenced by vaccination.

The main performance measure we concentrate on is the COVID CFR measured as total COVID deaths divided by total COVID cases in each and every country. CFR measures how many people died on COVID from those, who were infected. So, a country, where it was many cases with low mortality ranks much better than a country with low number of infected, but high COVID mortality. In a nutshell, this indicator reflects the true capability of the healthcare 
system to deal with COVID. It does not evaluate public health measures or actions related to isolation or lockdowns (which would influence the number of infected first of all). It shows how the healthcare system was capable and able to deal with those, who were already infected, and how many of these infected died.

We explain the COVID case fatality rate ("CASE.FATALITY.RATE”) and related relationships by the following variables:

1. "Joumard.2010" - classification of healthcare system organization - dummy variable

2. "EHCI.score" = European Health Consumer Index 2018 performance score

3. "covid.CASES" = total COVID cases per million, April 23, 2021

4. "covid.DEATHS" = total COVID deaths per million, April 23, 2021

5. “covid.TESTS" = total COVID tests per million, April 23, 2021

6. "population" = total population of the country, 2020

7. "area" = total area of the country, 2020

8. "REAL.GDP.per.capita” = real GDP per capita, 2020

We also explain case fatality rate (variable "CASE.FATALITY.RATE") also by EHCI subscores: (1) Rights, information, eHealth, (2) Accessibility, (3) Outcomes, (4) Generosity, (5) Prevention and (6) Pharmaceuticals.

\section{RESULTS}

\subsection{Correlation analysis}

In the first step, we consider all variables, and we perform correlation analysis (Spearman's correlation coefficient), which describes multiple relations (Fig. 3). Among all variables, correlation coefficient between EHCI score and CFR is closest to one in absolute value. EHCI score has significantly positive relationship with real GDP $(P$-value $=0.0001508)$ and negative relationship with total COVID deaths $(P$-value $=0.03156)$ and case fatality rate $(P$-value $=$ 8.168e-05).

Number of COVID tests performed is positively correlated to EHCI score and real GDP and negatively correlated to population, total area, and CFR. All of them are statistically non-significant. Correlation coefficient between total tests performed and total COVID cases is near zero. Logically, there is a strong relationship between total COVID cases and deaths, on the other hand correlation between number of cases and CFR is near zero.

Real GDP has significantly negative correlation coefficient with total COVID deaths $(P$-value $=0.00149)$ and CFR $(P$-value $=8.855 \mathrm{e}-05)$. While the number of total COVID deaths has a stronger negative relationship with real GDP, CFR has a stronger relationship with EHCI score.

\subsection{Multiple regression analysis}

With outcomes from correlation analysis there is an assumption, that not all variables are suitable for linear regression model because of their dependencies. According to the results of correlation analysis, we choose to build a model to analyse how our target variable (CFR) depends on the variables, such as EHCI score, real GDP, number of COVID cases, number of COVID tests performed, categorical variable groups from Joumard's analysis, ratio of total 


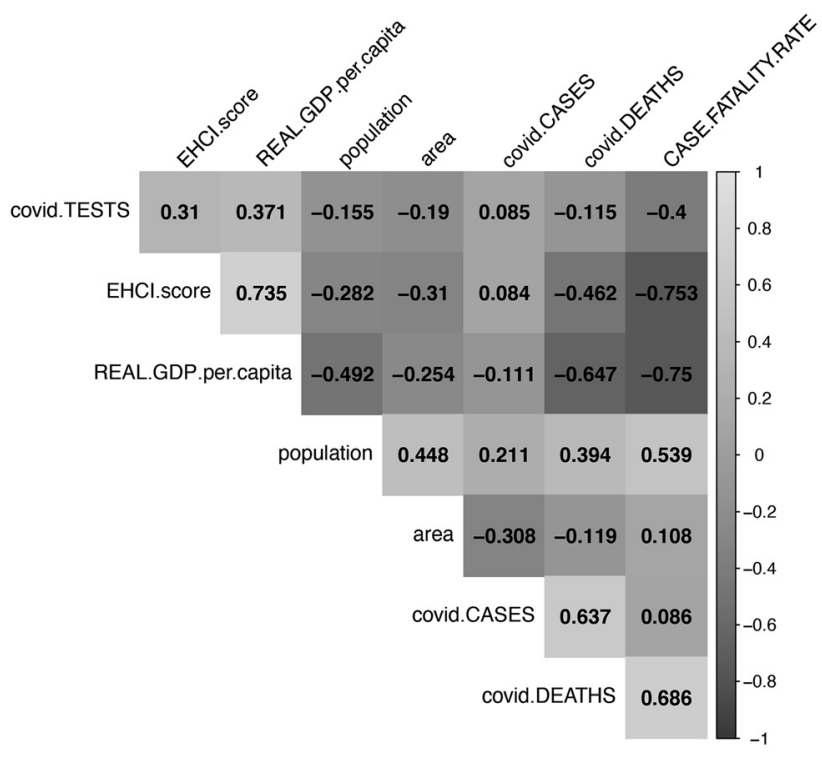

Source: Own calculations

Fig. 3. Correlation analysis case fatality rate and all variables

Note: The variations in grey color represent the strength of the correlation from -1 (very dark) to +1 (very light).

population and area (i.e., density of population). Our initial model produces $R^{2}=0.853$ and adjusted $R^{2}=0.6912$.

Due to the expected multicollinearity, we calculate variance inflation factor (VIF) among predictors. VIFs of predictors detect collinearity in our model, therefore we use backward elimination based on the Akaike information criterion. Stepwise model selection left variables: EHCI score, Joumard's groups, population, and density, with $R^{2}$ of the model 0.851 and adjusted $R^{2} 0.7593$ (Fig. 4). The model shows that the most significant variable is EHCI score $(P$-value $=$ 2.65e-05).

\section{3. $\mathrm{EHCl}$ sub-scores model}

Since EHCI score plays a noticeable part in the coefficient of determination of the model, we look at EHCI sub-scores separately (Fig. 5). There are negative relationships with all EHCI category sub-scores and CFR.

Significantly negative relationships are between CFR and categories: Rights, information, and E-health $(P$-value $=0.0006027)$, Outcomes $(P$-value $=0.0004104)$ and Generosity $(P$-value $=7.459 \mathrm{e}-05)$. Correlations with the other three categories are non-significant. 


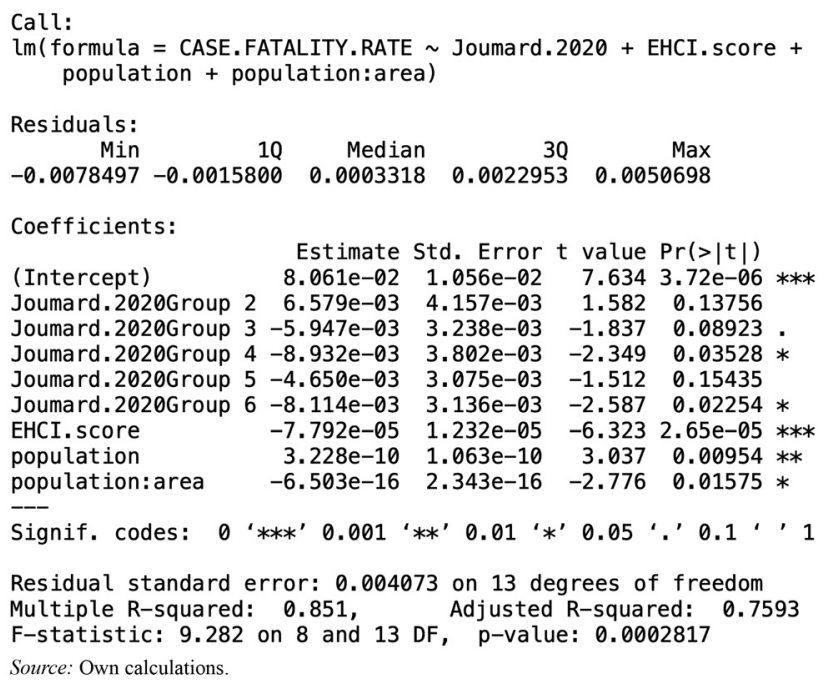

Fig. 4. Multiple regression analysis

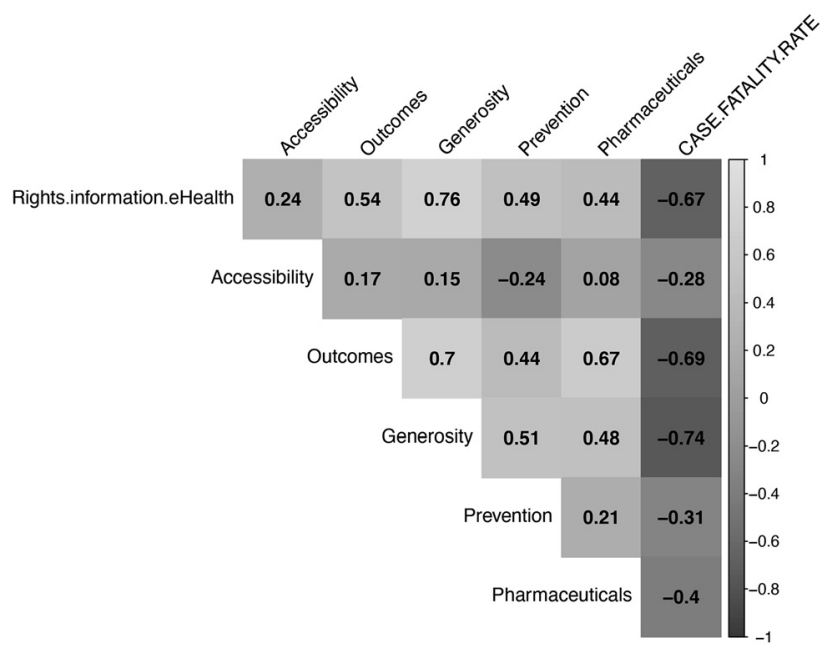

Source: Own calculations.

Fig. 5. Correlation analysis case fatality rate and EHCl sub-scores

Note: See Fig. 4. 
Table 2. EHCl sub-scores by categories

\begin{tabular}{|c|c|c|c|c|c|c|c|}
\hline & $\begin{array}{c}\text { Rights, } \\
\text { information, } \\
\text { eHealth }\end{array}$ & $\begin{array}{l}\text { Accessi- } \\
\text { bility }\end{array}$ & Outcomes & Generosity & Prevention & $\begin{array}{l}\text { Pharma- } \\
\text { ceuticals }\end{array}$ & $\begin{array}{c}\text { CASE } \\
\text { FATALITY RATE }\end{array}$ \\
\hline Country & $\begin{array}{c}\text { Max } \\
\text { score }= \\
125\end{array}$ & $\begin{array}{c}\text { Max } \\
\text { score }= \\
225\end{array}$ & $\begin{array}{c}\text { Max } \\
\text { score }= \\
300\end{array}$ & $\begin{array}{c}\text { Max } \\
\text { score }= \\
125\end{array}$ & $\begin{array}{c}\text { Max } \\
\text { score }= \\
125\end{array}$ & $\begin{array}{c}\text { Max } \\
\text { score }= \\
100\end{array}$ & $\begin{array}{c}\text { covid. } \\
\text { DEATHS/ } \\
\text { covid. CASES }\end{array}$ \\
\hline Switzerland & 113 & 225 & 278 & 99 & 95 & 83 & 0.0163 \\
\hline Netherlands & 125 & 175 & 256 & 125 & 113 & 89 & 0.0118 \\
\hline Norway & 125 & 138 & 278 & 120 & 119 & 78 & 0.0067 \\
\hline Denmark & 121 & 175 & 267 & 120 & 95 & 78 & 0.0100 \\
\hline Belgium & 104 & 213 & 244 & 115 & 101 & 72 & 0.0248 \\
\hline Finland & 113 & 150 & 278 & 120 & 101 & 78 & 0.0106 \\
\hline Luxembourg & 100 & 188 & 244 & 109 & 95 & 72 & 0.0120 \\
\hline Sweden & 117 & 113 & 267 & 125 & 101 & 78 & 0.0148 \\
\hline Austria & 108 & 175 & 244 & 104 & 89 & 78 & 0.0166 \\
\hline Iceland & 121 & 188 & 222 & 104 & 107 & 56 & 0.0046 \\
\hline France & 104 & 188 & 233 & 104 & 83 & 83 & 0.0189 \\
\hline Germany & 104 & 163 & 244 & 83 & 101 & 89 & 0.0252 \\
\hline Portugal & 108 & 163 & 222 & 94 & 89 & 78 & 0.0204 \\
\hline Czechia & 108 & 175 & 211 & 104 & 71 & 61 & 0.0179 \\
\hline U.K. & 117 & 100 & 211 & 109 & 113 & 78 & 0.0290 \\
\hline Slovakia & 113 & 188 & 200 & 78 & 77 & 67 & 0.0301 \\
\hline Spain & 96 & 113 & 222 & 94 & 101 & 72 & 0.0224 \\
\hline Italy & 92 & 138 & 233 & 73 & 101 & 50 & 0.0302 \\
\hline Ireland & 83 & 75 & 244 & 94 & 89 & 83 & 0.0198 \\
\hline Greece & 67 & 163 & 200 & 52 & 83 & 50 & 0.0300 \\
\hline Poland & 79 & 138 & 167 & 57 & 89 & 56 & 0.0236 \\
\hline Hungary & 79 & 113 & 156 & 78 & 95 & 44 & 0.0343 \\
\hline
\end{tabular}

Source: Bjornberg (2019), Worldometers (2021b) and own calculation.

It is obvious from Tables 2 and 3, that for Hungary and Poland the gap in these three sub-scores is enormous compared to the average of the high performing countries. Czech Republic and Slovakia are doing quite well on the patients' rights and information sub-score but need to improve the outcomes. In generosity sub-score the V4 leader is Czech Republic with Slovakia low on the Hungarian level. 
Table 3. EHCl sub-scores by categories

\begin{tabular}{|c|c|c|c|c|c|c|c|}
\hline & $\begin{array}{l}\text { Patient rights, } \\
\text { information, and } \\
\text { e-Health }\end{array}$ & $\begin{array}{l}\text { Accessibility (Waiting } \\
\text { time for treatment) }\end{array}$ & Outcomes & $\begin{array}{l}\text { Range and reach of } \\
\text { services ("Generosity") }\end{array}$ & Prevention & Pharmaceuticals & Total \\
\hline $\begin{array}{l}\text { High performers average } \\
\text { (above EHCl score } \\
\text { median) }\end{array}$ & 114 & 175 & 256 & 113 & 100 & 77 & 834 \\
\hline Czech Republic & 108 & 175 & 211 & 104 & 71 & 61 & 730 \\
\hline Slovakia & 113 & 188 & 200 & 78 & 77 & 67 & 723 \\
\hline Poland & 79 & 138 & 167 & 57 & 89 & 56 & 586 \\
\hline Hungary & 79 & 113 & 156 & 78 & 95 & 44 & 565 \\
\hline
\end{tabular}

Source: Bjornberg (2019). 


\subsection{COVID CFR explained by EHCl scores and the Joumard Grouping}

Combined classification by Joumard groups and EHCI scores showed a very interesting picture (Fig. 6). There are two almost empty quadrants. If a country's EHCI score is under median (790.5 points), the COVID CFR is not likely to fall under $1.9 \%$. By contrast, if the country is a member of the wider "Club 800 ", the country's COVID CFR is most likely under $1.9 \%$. So, the countries pile up basically in two quadrants. High EHCI performers with low CFR (below 1.9\%) and low EHCI performers with high COVID CFRs.

With a small exception of Czech Republic, the V4 countries are not doing very well in fighting COVID. Hungary is the worst not only from the V4 group, but the worst from the whole list of 22 European countries included in this research. Poland is doing better, but still is high above the median death rate. Interestingly, almost all "group 6" countries (except Norway) are not performing good, which might reflect some deep systematic problem. Slovakia is the second worst from the V4 group and together with other "group 1" countries form certain "envelope" around the rest of the countries. Czech Republic is the best performer not only from V4, but from all countries below 790.5 EHCI score (median). Czech Republic is the "exemption that confirms the rule" - the country with EHCI score lower than median and CFR also lower than the median.

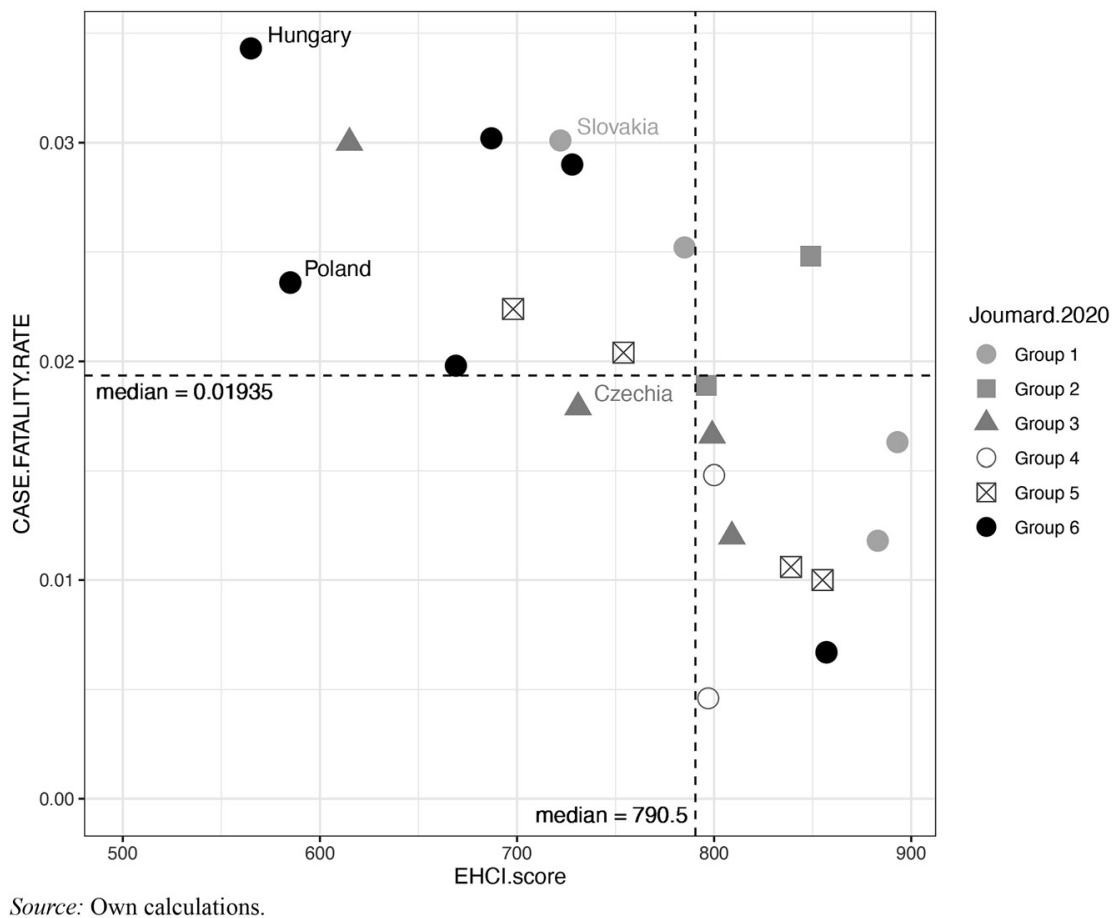

Fig. 6. COVID case fatality rate explained by $\mathrm{EHCl}$ scores and Joumard Groupings 


\section{CONCLUSIONS}

There are several important conclusions from our research:

1. Literature review showed that the COVID papers can be classified into three groups. The first type is the studies on risk factors that can cause death from COVID. The second type of studies focus on socioeconomic, public health or environment determinants. The third type of studies look at partial indicators of health systems. So, there is an absolute lack of studies that focus on variability on CFR with the holistic view on the organization of health systems as an aggregate.

2. Our model $\left(R^{2}=0.851, P\right.$ value $\left.=0.0002817\right)$ shows that EHCI score is the most important variable to explain COVID CFR. Furthermore, EHCI score has a negative beta $\left(R^{2}\right.$ only for EHCI $=0.5056)$. This means that higher EHCI score is related to lower CFR. Population density also plays a role, with positive beta (correlation coefficient $=0.22$ ) and means that higher population density means higher COVID CFR.

3. Combined classification by Joumard groups and EHCI showed that the countries pile up basically in two quadrants. High EHCI performers with low CFR (below 1.9\%) and low EHCI performers with high COVID CFRs.

4. There is no clear statement about which Joumard "group" managed the COVID pandemic as best. Rather the result shows, that high EHCI performance is a more important indicator than the groups itself. And this implies a very important message, that if the country fails to perform good in "non pandemics" times it will also fail during pandemics. And vice versa, if a country is good in managing its health system in good times, so it does in bad times, too.

5. Therefore, if the V4 countries want to increase their ability to manage pandemics like COVID, they should focus on improving their own healthcare system performance. As our research indicated, they should especially increase the following three sub-scores: the (1) patient rights, information, and e-health, (2) outcomes and (3) generosity of the healthcare system.

Our research showed a need for more systematic analysis related to COVID pandemics and opened further questions. Why 5 out of 6 countries from the "group 6" are low performing countries with high covid death rate? Besides Hungary and Poland, it is Ireland, Italy and UK. The only exemption from this group is Norway - a high performer with lowest CFR among all 22 analysed countries. In this case, a combination of high EHCI score and low population density played an important role most probably. Further on, why do the "group 1" countries form an envelope around all other countries? Shall this indicate, that in relative terms, these countries (Netherlands, Switzerland, Germany) are doing quite well but not so well as their closest performance peers? And the final question, that reminds rather a warning than a question mark. CFRs of COVID are closely linked to the chronic diseases and vulnerable population, so if a country is weak in taking care of chronic and vulnerable patients, it will be weak in taking care of the COVID patients. And addressing these organizational gaps and improving these performance parameters is a question of decades, not months. 


\section{REFERENCES}

Adams, M. L. (2021): Global Association of Obesity and COVID-19 Death Rates. medRxiv. https://doi.org/ 10.1101/2021.03.09.21253222.

American Diabetes Association (2021): How COVID-19 Impacts People with Diabetes. https://www. diabetes.org/coronavirus-covid-19/how-coronavirus-impacts-people-with-diabetes.

Asthma UK - British Lung Foundation Partnership (2021): What should People with Asthma do Now? https://www.asthma.org.uk/advice/triggers/coronavirus-covid-19/what-should-people-with-asthmado-now/.

Björnberg, A. (2019): Euro Health Consumer Index 2018. Report. Health Consumer Powerhouse. https:// healthpowerhouse.com/media/EHCI-2018/EHCI-2018-report.pdf.

British Heart Foundation (2021): Coronavirus: What it Means for You if You Have Heart or Circulatory Disease. https://www.bhf.org.uk/informationsupport/heart-matters-magazine/news/coronavirus-andyour-health\#Heading2.

British Liver Trust (2021): Coronavirus (COVID-19) - Health Advice for People with Liver Disease and Liver Transplant Patients. https://britishlivertrust.org.uk/coronavirus-covid-19-health-advice-forpeople-with-liver-disease-and-liver-transplant-patients/.

Cancer Research UK (2021): Coronavirus (COVID-19) and Cancer. https://www.cancerresearchuk.org/ about-cancer/cancer-in-general/coronavirus/covid-19-and-cancer.

CDC (2021a): People with Certain Medical Conditions. https://www.cdc.gov/coronavirus/2019-ncov/needextra-precautions/people-with-medical-conditions.html.

CDC (2021b): Obesity, Race/ethnicity, and COVID-19. https://www.cdc.gov/obesity/data/obesity-andcovid-19.html.

CDC (2021c): Older Adults. Older Unvaccinated Adults Are More Likely to Be Hospitalized or Die from COVID-19. https://www.cdc.gov/coronavirus/2019-ncov/need-extra-precautions/older-adults.html.

Cheng, K. J. G. - Sun, Y. - Monnat, S. M. (2020): COVID-19 Death Rates Are Higher in Rural Counties with Larger Shares of Blacks and Hispanics. The Journal of Rural Health, 36(4): 602-608.

Clark, C. E. - McDonagh, S. T. J. - McManus, R. J. - Martin, U. (2021): COVID-19 and Hypertension: Risks and Management. A Scientific Statement on Behalf of the British and Irish Hypertension Society. Journal of Human Hypertension, 35: 304-307.

Danska-Borsiak, D. (2019): Determinants of Total Factor Productivity in Visegrad Group Nuts-2 Regions. Acta Oeconomica, 69(1): 31-50.

Delanghe, J. R. - De Buyzere, M. L. - De Bruyne, S. - Van Criekinge, W. - Speeckaert, M. (2020): The Potential Influence of Human Y-Chromosome Haplogroup on COVID-19 Prevalence and Mortality. Annals of Oncology: Official Journal of the European Society for Medical Oncology, 31(11): 1582-1584.

Dincă, G. - Dincă, M. S. - Andronic, M. L. (2020): The Efficiency of the Healthcare System in Several EU Member States. Acta Oeconomica, 70(1): 19-36.

Doti, J. L. (2020): A Model to Explain State-Wide Differences in COVID-19 Death Rates. http://dx.doi.org/ $10.2139 /$ ssrn. 3731803.

ECDC (2021): Overview of the Implementation of COVID-19 Vaccination Strategies and Deployment Plans in the EU/EEA. May, 6 2021. https:/www.ecdc.europa.eu/sites/default/files/documents/covid-19overview-vaccination-strategies-deployment-plans-6-may-2021.pdf.

Eurostat (2021): Database, available at https://ec.europa.eu/eurostat/data/database. 
Fisher, Sh. - Gould, J. - Haughton, T. (2007): Slovakia's Neo-liberal Turn. Europe-Asia Studies, 59(6): 977998. https://www.tandfonline.com/doi/abs/10.1080/09668130701489170".

Gadarian, S. K. - Goodman, S. W. - Pepinsky, T. B. (2021): Partisanship, Health Behavior, and Policy Attitudes in the Early Stages of the COVID-19 Pandemic. PloS One, 16(4): e0249596. https://doi.org/10. 1371/journal.pone.0249596.

Gardiner, J. - Oben, J. - Sutcliffe, A. (2021): Obesity as a Driver of International Differences in COVID-19 Death Rates. Diabetes, Obesity and Metabolism. https://doi.org/10.1111/dom.14357.

Ibrahim, M. - Salih, A. (2021): The Y Chromosome Ancestry Marker R1b1b2: A Surrogate of the SARSCoV-2 Population Affinity. Human Genome Variation, 8(11). https://doi.org/10.1038/s41439-02100141-1.

Joumard, I. - André, Ch. - Nicq, Ch. (2010): Health Care Systems: Efficiency and Institutions. OECD Economics Department Working Papers, No. 769, OECD Publishing. https://doi.org/10.1787/ $5 \mathrm{kmfp} 51 f 5 f 9 t-e n$.

Knittel, C. R. - Ozaltun, B. (2020): What does and does not Correlate with COVID-19 Death Rates. NBER Working Paper, No. 27391.

Kozuń-Cieślak, G. (2020): Is the Efficiency of the Healthcare System Linked to the Country's Economic Wealth? Beveridgeans Versus Bismarckians. Acta Oeconomica, 70(1): 1-17.

Lescure, F. X. - Bouadma, L. - Nguyen, D. - Parisey, M. - Wicky, P. H. - Behillil, S. - Gaymard, A. Bouscambert-Duchamp, M. - Donati, F. - Le Hingrat, Q. - Enouf, V. (2020): Clinical and Virological Data of the First Cases of COVID-19 in Europe: A Case Series. The Lancet Infectious Diseases, 20(6): 697-706, https://doi.org/10.1016/S1473-3099(20)30200-0.

Liang, L. L. - Tseng, CH. - Ho, H. J. - Wu, C. Y. (2020): Covid-19 Mortality is Negatively Associated with Test Number and Government Effectiveness. Scientific Reports, 10, 12567. https://doi.org/10.1038/ s41598-020-68862-x.

Luo, Y. - Yan, J. - McClure, S. (2021): Distribution of the Environmental and Socioeconomic Risk Factors on COVID-19 Death Rate Across Continental USA: A Spatial Nonlinear Analysis. Environment Scientific Pollution Research, 28: 6587-6599.

Mattiuzzi, C. - Lippi, G. - Henry, B. M. (2021): Healthcare Indicators Associated with COVID-19 Death Rates in the European Union. Public Health, 193: 41-42.

National Kidney Foundation (2021): Kidney Disease \& COVID-19. https://www.kidney.org/coronavirus/ kidney-disease-covid-19.

NHS (2021): Who is at High Risk from Coronavirus (Clinically Extremely Vulnerable). https://www.nhs. $\mathrm{uk} /$ conditions/coronavirus-covid-19/people-at-higher-risk/who-is-at-high-risk-from-coronavirusclinically-extremely-vulnerable/.

Ruck, D. J. - Borycz, J. - Bentley, R. A. (2021): Cultural Values Predict National COVID-19 Death Rates. SN Social Sciences, 1: 74. https://doi.org/10.1007/s43545-021-00080-2.

Schillaci, S. (2021): Timeline of the Works on the Correlation between COVID-19 and Y-DNA Haplogroup $R 1 b$. https://doi.org/10.31219/osf.io/gvxjw.

Smatana, M - Pažitný, P - Kandilaki, D - Laktišová, M - Sedláková, D - Palušková, M - van Ginneken, E Spranger, A (2016): Slovakia: Health System Review. Health Systems in Transition, 18(6): 1-210.

Stroke Association (2021): Information on Coronavirus for Stroke Survivors. https://www.stroke.org.uk/ finding-support/information-coronavirus-stroke-survivors.

The British Diabetic Association (2021): Updates: Coronavirus and Diabetes. https://www.diabetes.org.uk/ about_us/news/coronavirus. 
Wang, Q. - Davis, P - Gurney, M - Xu, R. (2021): COVID-19 and Dementia: Analyses of Risk, Disparity, and Outcomes from Electronic Health Records in the US. Alzheimer's \& Dementia: The Journal of the Alzheimer's Association. https://doi.org/10.1002/alz.12296.

Worldometer (2021a): Number of Covid Cases as of June 24, 2021. https://www.worldometers.info/ coronavirus/\#countries.

Worldometer (2021b): Number of Covid Cases, Covid Tests and Covid Deaths as of April 23, 2021. https:// www.worldometers.info/coronavirus/\#countries. 